\title{
The Investment Efficiency of Family Firm in the Pandemic Era
}

\author{
Ni Made Adi Erawati ${ }^{1,{ }^{*}}$ Bambang Hariadi ${ }^{2}$ Kadek Indah Kusuma Dewi ${ }^{3}$ \\ ${ }^{1}$ Udayana University, Indonesia \\ ${ }^{2}$ Brawijaya University, Indonesia \\ ${ }^{3}$ Mahasaraswati University, Indonesia \\ "Corresponding author.Email: adierawati@unud.ac.id
}

\begin{abstract}
This research aims to find how the disclosure of corporate social responsibility (CSR) as a moderation effect of family ownership on investment efficiency. Total samples are 90 family businesses of manufacturing companies listed on the Indonesia Stock Exchange (IDX) in a period of 2018-2020 and analyzed by Statistical Package for the Social Sciences (SPSS). This research finds that CSR disclosure can moderate the relationship between family ownership and investment efficiency. It also shows that family businesses will avoid risk by being more careful when making investment decisions concerning family reputation.
\end{abstract}

Keywords: Investment Efficiency, CSR, Family Ownership.

\section{INTRODUCTION}

The Corona Virus Disease-19 (Covid-19) at the end of 2019 had a huge impact on the world until now. It was recorded that until the end of 2020 there were 735,124 positive Covid-19 people in Indonesia [1]. The increasing number of positive cases ultimately affects all aspects of society, from individuals to corporations.

One of the important issue in Indonesia is bad level of investment efficiency. Based on Bapenas data in 2019, recorded Indonesia is categorized as quite bad compared to other ASEAN countries. The investment efficiency of the company can affect the macroeconomic growth [2]. This concluded that the investment efficiency of a country is a reflection of the investment efficiency of companies in that country, so for 2020 as the bad impact of pandemic in Indonesia many corporations experiencing financial distress even bankrupt.

Investment efficiency is an ideal or optimal investment condition that the company should make. An investment is efficient if there is no deviation, either positive or negative. Investment efficiency can measure the company's Net Present Value [3] for optimal investment, not overinvestment or underinvestment [4]. Overinvestment indicates the company is investing above the target, which causes a positive deviation. Conversely, negative deviation occurs if the company invests below the target or underinvestment. Overinvestment or underinvestment will not occur if the company invests optimally or investment efficiently. The company's investment efficiency will be able to continue the business to future generations and make a major contribution to the economic growth of a country [5].

In Indonesia, most companies are family business enterprises that play big role [6]. There are factors of family values and culture in the family system that become pride in itself, showing strong identification and commitment [7], it because of the previous generation passed down the values to uphold and understand the obligations to the next generation [8]. However, from ownership and management, family companies have a different character than non-family companies [9]. Call it the term family reason over business logic and family members who are very influential so that they can attract revenue for personal interests [10]. Weaknesses also arise in family companies such as family members outside the organization interfering so that the family company becomes a confusing organization and tolerance for incompetence.

Family involvement in the company and occupying a strategic position in decision-making will weaken investment efficiency [11]. It is because 
family companies have different considerations from non-family companies in making decisions. Socioemotional wealth is an important consideration in decision making, including investment decisions. Socio-emotional wealth is company aspect of nonfinancial that is used to complete the family affective needs [12]. Family companies tend to take overinvestment or underinvestment positions to protect socio-emotional wealth [13]. The tendency to invest long-term and choose to hold cash causes family companies to invest under optimal or underinvestment [14] [15].

Socio-emotional wealth of family companies value such as prestige and preservation of family dynasties more than financial benefits. Family companies disclose more about CSR activities that can affect the relationship of company with its environment compared to information about shareholders [16]. Family companies get consideration of CSR investment for long-term financial benefits [17] [18].

\section{LITERATURE REVIEW}

\subsection{Socio-Emotional Wealth (SEW)}

Socio-emotional wealth can be in the form of image, family name, family values, family culture, family dynasty, and family social capital. The existence of strong family values supports the development of corporate culture. Preservation of family values will become the family business's culture, social capital, and pillar. Preservation of family values is done through company activities [19]. When faced with a choice, firms with family ownership choose to consider non-financial rather than financial goals [12]. This socio emotional wealth approach is used for identify the family ownership concept [20] [21].

\subsection{Stakeholder Theory}

The stakeholders are individuals or groups who can influence and/or be influenced [22]. Stakeholder theory and CSR are two concepts that look at the same business problem from different perspectives [23]. The high CSR disclosure is associated with high investment efficiency [24], governance encourages CSR disclosure [25].

\subsection{Legitimacy Theory}

There is a match between what the community provides and what the company needs in the community [26]. Legitimacy theory, state the motivation of company to gain legitimacy through CSR activities to improve the company image [27].

\subsection{Investment Efficiency}

Conceptually, investment efficiency is optimal investment, meaning that companies take projects that produce optimal investments [28]. The overinvestment and underinvestment are two types of inefficient investment deviation activities for companies [2]. An overinvestment position is when a company invests beyond its capacity so that it requires external funds which incur additional costs. On the other hand, an underinvestment position is when the company invests below its ability so that there is an investment opportunity that the company misses.

\subsection{Corporate Social Responsibility Disclosure (CSR)}

CSR explains the expansion of accounting reports to include information about products, employees, social activities, and environmental impacts [29]. The purpose of corporate CSR disclosure is to improve (1) corporate image, (2) accountability, and (3) expansion of traditional disclosure [29]. There are two types of disclosure, namely mandatory disclosure and voluntary disclosure. This means that disclosure of the impact of company activities on the environment, responsibility to the community including the costs of these impacts is important [30].

\subsection{Family Ownership}

Family ownership is a term used for companies with a concentration of family ownership or commonly referred to as family firms. Family firms are unique in the decision-making process [12]. Nonfinancial factors, such as image, prestige, and family name are important considerations even though they are still aimed at making a profit. Having family members in the company will ensure that family values are maintained. Preservation of socioemotional wealth is an affective need for family company owners. This causes family companies to be very careful in making investment decisions, so that socioemotional wealth, such as image and family name is not threatened [12]. 


\subsection{Family Ownership and Investment Efficiency}

According to the socio-emotional wealth perspective, family ownership in company make the next generation use it to flow the business [12]. Family controls the company investment activities always reminding management of family values in decision making so that family ownership affects investment efficiency [31]. Family firms tend to underinvest and retain more cash post-IPO [13]. Companies with family ownership found a contradiction between family ownership and investment efficiency [11]. Instead, they will reduce socio-emotional wealth by avoiding risky decisions that might increase economic wealth [32]. The greater the role and control of the family in the company, the lower the investment efficiency [11]. The collection of "endowments" for the next generation causes family companies to tend to withhold dividends which cause underinvestment [33]. The greater the family ownership, the lower the investment efficiency [14]. Based on theoretical studies and previous research, the hypothesis is formulated below.

$\mathrm{H}_{1}$ : Family ownership has a negative effect on investment efficiency.

\subsection{Family Ownership, Corporate Social Responsibility Disclosure, and Investment Efficiency}

Family firms show more concern for the environment and prevention using conservative strategies [34] [35]. In America, family companies are more interested in CSR activities [17]. Companies can identify the most important CSR components in increasing investment efficiency [36] [31]. From the theoretical description and previous research, the formulated hypothesis as following.

$\mathrm{H}_{2}$ : CSR disclosure weakens the effect of family ownership on investment efficiency.

\section{RESEARCH METHODS AND MATERIALS}

\subsection{Research Design}

Manufacturing companies from IDX used in this research for the period 2018-2020. The secondary data used in this research include annual reports, financial and sustainability reports with the help of SPSS software.

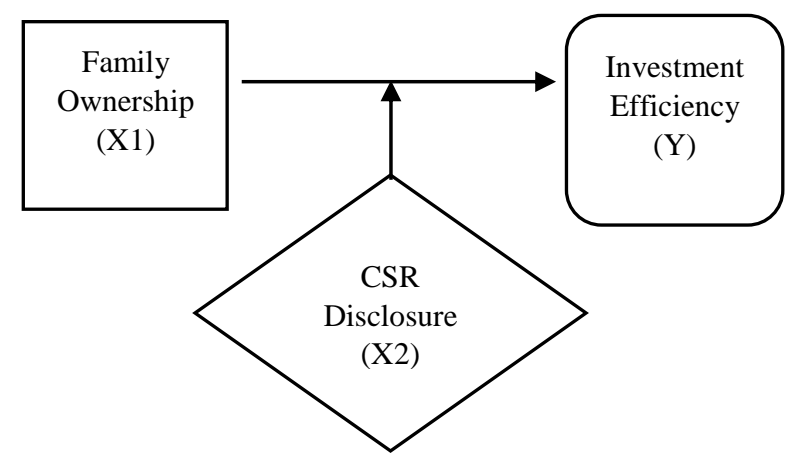

Figure 1 Conceptual Framework

\subsection{Measurement Variables}

The dependent variable in this research is investment efficiency. Absolute residuals multiplied by 1 are used in this research to calculate investment efficiency, which shows that the level of investment is not optimal from the expected level of investment [37]. A negative NPV indicates that overinvestment will provide a positive residual value, while underinvestment is indicated by a negative residual value obtained from a positive NPV. The formula is as follows:

$\mathrm{Y}_{\mathrm{i}, \mathrm{t}}=\beta_{0}+\beta_{1}$ Sales Growth $_{\mathrm{i}, \mathrm{t}-1}+\varepsilon_{\mathrm{i}, \mathrm{t}}$

$\mathrm{Y}$ is total investment of the company in the year $\mathrm{t}$, while Sales Growth $\mathrm{h}_{\mathrm{i}, \mathrm{t}-1}$ is change in company sales in year $\mathrm{t}$ compared to year $(\mathrm{t}-1)$

Family ownership as independent variable in this research is measured by family members proportion consist of the board members of commissioners and or directors of the company [31]. CSR disclosure as a moderating variable of the effect of family ownership on investment efficiency. The measurement of CSR disclosure uses the quality disclosure model of Raar (2002) [38].

\section{RESULTS AND DISCUSSION}

\subsection{Descriptive Statistics}

The research results shown by Table 1 are descriptive statistics, which provide an overview of the data in this research.

Table 1 informs that the investment efficiency of manufacturing sectors listed on the IDX in 2018-2020 is the lowest at -43.60 and the highest at -0.02 . The company with the highest investment efficiency is 
ASII, while the company with the lowest investment efficiency is YPAS. The average investment efficiency is -5.41 and the standard deviation is 7.41 , meaning that the investment efficiency is concentrated at $-5.41 \pm 7.41$. This shows that the average investment efficiency of family firms on the IDX is still not optimal and tends to be underinvested.

And also, in 2020 which the Covid-19 happened, the investment efficiency is underinvestment because it shows the negative residuals value, which means the investment from companies used in this research is not optimal. Sales growth, which is one of the components of calculating investment efficiency, shows that $76.67 \%$ of the companies sampled by the researcher experienced a decline in sales in 2020 due to the pandemic. The decline even reached $99 \%$ in 2020 from the previous year.

Table 1. Descriptive Statistics

\begin{tabular}{|l|c|c|c|c|c|}
\hline & N & Min. & Max. & Mean & $\begin{array}{c}\text { Std } \\
\text { Dev }\end{array}$ \\
\hline $\begin{array}{l}\text { Family } \\
\text { Ownership } \\
\text { (X1) }\end{array}$ & 90 & 0.00 & 0.86 & 0.24 & 0.23 \\
\hline $\begin{array}{l}\text { CSR } \\
\begin{array}{l}\text { Disclosure } \\
\text { (X2) }\end{array}\end{array}$ & 90 & 3.00 & 7.00 & 4.16 & 1.38 \\
\hline $\begin{array}{l}\text { Investment } \\
\text { Efficiency } \\
\text { (Y) }\end{array}$ & 90 & -43.60 & -0.02 & -5.41 & 7.41 \\
\hline
\end{tabular}

The family members involvement in the company, both as commissioners and directors, is quite high, with an average of 23.74 percent, there are even companies with the proportion of family directors and commissioners more than 70 percent. The standard deviation of 0.23 means that the proportion of family roles is concentrated at $0.24 \pm 0.23$.

CSR disclosure follows the Raar model (2002) with scores ranging from 1 to 7 . Most of them, namely 50 percent of companies get a score of 3 , meaning that CSR disclosure is qualitatively in the form of a description of CSR activities carried out by the company. Only 14.4 percent of companies get a score of 7 or a maximum score, meaning that the company fully discloses its CSR activitiesThis shows that the company's awareness is still low to fully disclose its social responsibility activities.

\subsection{Hypothesis Test}

There are two equations used in this research:

$$
\begin{array}{ll}
\mathrm{Y} & =\mathrm{a}+\mathrm{b} 1 \mathrm{X} 1 \\
\mathrm{Y} & =\mathrm{a}+\mathrm{b} 1 \mathrm{X} 1+\mathrm{b} 2 \mathrm{X} 2+\mathrm{b} 3 \mathrm{X} 1 \mathrm{X} 2
\end{array}
$$

Equation 1 is a model made to determine the effect of family firm ownership on investment efficiency, which was carried out using a simple linear regression test. Based on several tests that have been carried out, a summary of the results of the analysis in Table 2 and Table 3 below.

Table 2. Regression Analysis Result Equation 1

\begin{tabular}{|l|c|c|}
\hline \multicolumn{2}{|c|}{$=\mathrm{a}+\mathrm{b} 1 \mathrm{X} 1$} \\
$\mathrm{Y}$ & $=0,988-0,856 \mathrm{X} 1$ & \\
\hline \multicolumn{1}{|c|}{ Variable } & $\begin{array}{c}\text { Beta } \\
\text { Coefficient }\end{array}$ & Significance \\
\hline Constant & 0,988 & 0,000 \\
Family & $-0,856$ & 0,001 \\
Ownership & & \\
(X1) & & \\
\hline F Value & 11,272 & \\
\hline F Sig & 0,001 & \\
\hline Adjusted R & 0,103 & \\
\hline
\end{tabular}

Table 2 shows an $\mathrm{F}$ value of 11.272 and a probability of 0,001 indicating that the model is feasible to use. While the adjusted $\mathrm{R}^{2}$ value of 0,103 indicates that the family ownership variable affects investment efficiency by $10,3 \%$.

The first hypothesis states that family ownership has a negative effect on investment efficiency. The regression results in Table 2 shows that family ownership has a regression coefficient value of $-0,856$ and a probability value of 0,001 (less than $5 \%$ ) which is statistically significant. So it can be concluded that $\mathrm{H}_{1}$ is supported because family ownership has a negative effect on investment efficiency. This shows that the larger the proportion of families, both as commissioners and directors, the lower investment efficiency.

Table 3. Regression Analysis Result Equation 2

\begin{tabular}{|l|l|c|}
\hline \multicolumn{2}{|c|}{$=\mathrm{Y}+\mathrm{b} 1 \mathrm{X} 1+\mathrm{b} 2 \mathrm{X} 2+\mathrm{b} 3 \mathrm{X} 1 \mathrm{X} 2$} \\
$\mathrm{Y}=\mathrm{a}+\mathrm{b} 1 \mathrm{X} 1+\mathrm{b} 2 \mathrm{X} 2+\mathrm{b} 3 \mathrm{X} 1 \mathrm{X} 2$ \\
\hline \multicolumn{1}{|c|}{ Variables } & \multicolumn{1}{|c|}{$\begin{array}{c}\text { Beta } \\
\text { Coefficient }\end{array}$} & Significance \\
\hline $\begin{array}{l}\text { Constant } \\
\text { Family }\end{array}$ & 0,817 & 0,001 \\
$\begin{array}{l}\text { Ownership } \\
(\mathrm{X} 1)\end{array}$ & $-0,753$ & 0,003 \\
\hline $\begin{array}{l}\text { CSR } \\
\text { Disclosure } \\
(\mathrm{X} 2)\end{array}$ & 0,262 \\
\hline $\begin{array}{l}\text { Interactions } \\
\text { X1X2 }\end{array}$ & 0,242 \\
\hline F Value & 8,982 & 0,044 \\
\hline F Sig & 0,000 \\
\hline Adjusted $\mathrm{R}^{2}$ & 0,212 \\
\hline
\end{tabular}

Table 3 shows an $\mathrm{F}$ value of 8,982 and a probability of 0,000 indicating that the model is 
feasible to use. While the adjusted $\mathrm{R}^{2}$ value of 0,212 indicates that the variables of family firm ownership and CSR disclosure affect investment efficiency by $21,2 \%$

The regression results in Table 3 show that family ownership has a regression coefficient value of $-0,753$ and a probability value of 0,003 (less than $5 \%$ ) which is statistically significant. there is an interaction effect of family ownership with CSR on investment efficiency. If beta 1 is negative, significant or not and beta 2 is significant positive, which is the moderating variable that weakens the influence of X1 on Y. Based on the table above, the coefficient of Beta 1 is $-0,753$ and significant, while the coefficient of beta 3 is 0,242 and significant, it can be concluded that $\mathrm{H}_{2}$ is supported because disclosure of CSR weakens the negative effect of family ownership on investment efficiency.

\subsection{Family Ownership and Investment Efficiency}

The results of hypothesis testing $\mathrm{H}_{1}$ indicate that family ownership negatively affects investment efficiency. Family members have control to the company's policy mechanism. Family firms retain more cash so it tends to underinvestment [13]. Efforts to avoid risk loss of socio-emotional wealth cause a decrease in the quality of policy economic company investment [12].

Socio-emotional preservation wealth such as maintaining a family dynasty and bequeathing the business to the next generation becomes the primary goal of the family company even though it must take economically risky decisions [32]. Priority on socioemotional wealth makes family companies very sensitive to social problems and very careful in making policies investment so that it tends to be underinvestment [27].

\subsection{Family Ownership, Corporate Social Responsibility, and Investment Efficiency}

The results of testing the $\mathrm{H}_{2}$ are that CSR weakens the relationship between family ownership on investment efficiency. Family presence in companies is able to influence company policies, including CSR disclosure [17]. Considerations of company name and reputation may affect disclosure CSR. Family companies show more concern for the environment, focus more on prevention, and use conservative strategies [34].
In addition, the presence of CSR can weaken the negative effect of family ownership on investment efficiency. Family companies have an agenda and are active in social activities although they still have a profit orientation [15]. In accordance with stakeholder theory, the company operates not only for itself but also for stakeholder interests. Refers to legitimacy theory that companies need to obtain and maintain the company's legitimacy in society.

\section{CONCLUSIONS}

This research concludes that family ownership has negative effect on investment efficiency. It means family members have control to the company's policy mechanism. The larger the proportion of family members as directors and or as commissioners, the higher the investment efficiency. Also, the presence of CSR can weaken the negative effect of family ownership on investment efficiency. Family companies have an agenda and are active in social activities, although still have a profit orientation. Although most of the disclosures made by family companies are still below the minimum disclosure, the presence of CSR plays an important role in making investment decisions so that it affects investment efficiency.

This research also concludes that during pandemic sales growth, which is one of the components of calculating investment efficiency, $76.67 \%$ of the companies sampled by the researcher experienced a decline in sales in 2020. The decline even reached 99\% in 2020 from the previous year. Furthermore, in 2020 which the Covid-19 happened, the investment efficiency is underinvestment because it shows the negative residual value, which means the investment from companies used in this research is not optimal.

\section{REFERENCES}

[1] Flora, Maria, Update Corona 30 Desember 2020: 735.124 Positif Covid-19, Meninggal 21.944, Sembuh 603.741. Diakses pada 15 Juni 2021.(https://www.liputan6.com/news/read/444 5279/update-corona-30-desember-2020-35124 positif-covid-19-meninggal-21944-sembuh603741), 2020.

[2] Jin, X. \& Yu, J, Government Governance, Executive Networks and Corporate Investment 
Efficiency, China Finance Review International, 2017, 8(2), pp. 122-139.

[3] Gomariz, C.M.F. \& Ballesta, S.J.P, Financial Reporting Quality, Debt Maturity and Investment Efficiency, Journal of Banking and Finance, 2014, 40(1), pp. 494-506.

[4] Cook, K.A., Romi, A.M., Sanchez, D., \& Sanchez, J.M, The Influence of Corporate Social Responsibility on Investment Efficiency and Innovation, 2018, Texas Tech University, USA \& University of Texas at San Antonio, USA.

[5] Chen, F., Hope, O.K., Li, Q., \& Wang, X, Financial Reporting Quality and Investment Efficiency of Private Firms in Emerging Markets. Accounting Review, 2011, 86(4), pp. 1255-1288.

[6] Hanazaki, M. \& Liu, Q, Corporate Governance and Investment in East Asian Frms: Empirical Analysis of Family-Controlled Firms. Journal of Asian Economics, 2007, 18(1), pp. 76-97.

[7] Baur, M, Successors and The Family Business: Novel Propositions and A New Guiding Model for Effective Succession. The American Academy of Business Journal, 2014, 19(2).

[8] Dinh, T.Q., \& Calabro, A, Asian Family Firms Through Corporate Governance and Institutions: A Systematic Review of the Literature and Agenda for Future Research. International Journal of Management Reviews, 2018, pp. 1-26.

[9] Saito, T, Family firms and firm Performance: Evidence from Japan. Journal of the Japanese and International Economies, 2008, 22(4), pp. 620646.

[10] Susanto, A.B., Wijanarko, H., Susanto, P., \& Mertosono, S, Family Business. The Jakarta Consulting Group, 2008.

[11] Lin, James Juicia \& Yeh, Yin-Hua, Internal Capital Markets, Ownership Structure, and Investment Efficiency: Evidence from Taiwanese Business Groups. Pasific-Basin Finance Journal, 2020.

[12] Gomez-Mejia, L.R., Nuñez-Nickel, M., \& Gutierrez, I, The Role of Family Ties in Agency Contracts. Journal, Academy of Management, 2017, 44(1).

[13] Jain, B.A. \& Shao, Y, Family Involvement and Post-IPO Investment Policy. Family Business Review, 2014, 27(4), pp. 287-306.
[14] Lin, C.J., Wang, T., \& Pan, C.J, Financial Reporting Quality and Investment Decisions for Family Firms. Asia Pacific Journal of Management, 2015, 33(2), pp. 499-532.

[15] Erawati, NMA., Sutrisno, T., Hariadi, B., Saraswati, E, The Role of Corporate Social Responsibility in the Investment Efficiency: Is It Important?. Journal of Asian Finance, Economics and Business, 2021, 8(1), pp. 169-178.

[16] Campopiano, G. \& De Massis, A, Corporate Social Responsibility Reporting: A Content Analysis in Family and Non-family Firms. Journal of Business Ethics, 2014, 129(3), pp. 511-534.

[17] Lamb, N.H. \& Butler, F.C, The Influence of Family Firms and Institutional Owners on Corporate Social Responsibility Performance. Business and Society, 2016, 57(7), pp. 13741406.

[18] Cabeza-García, L., Sacristán-Navarro, M., \& Gómez-Ansón, S, Family Involvement and Corporate Social Responsibility Disclosure. Journal of Family Business Strategy, 2017, 8(2), pp. 109-122.

[19] Dyer, W.G., \& Whetten, D.A, Family Firms and Social Responsibility: Preliminary Evidence from the S\&P 500. Entrepreneurship: Theory and Practice, 2006, 801, pp. 785-803.

[20] Miller, I.L.B., Miller, D., \& Lester, R.H, Stewardship or Agency? A Social Embeddedness Reconciliation of Conduct and Performance in Public Family Businesses. Organization Science, 2011, 22(3), pp. 704-721.

[21] Zellweger, T.M., Nason, R.S., Nordqvist, M., \& Brush, C.G, Why Do Family Firms Strive for Non Financial Goals? An Organizational Identity Perspective. Entrepreneurship: Theory and Practice, 2013, 37(2), pp. 229-248.

[22] Friedman, A.L. \& Miles, S, Developing Stakeholder Theory. Journal of Management Studies, 2002, 39(1), pp. 1-21.

[23] Freeman, R.E. \& Dmytriyev, S, Corporate Social Responsibility and Stakeholder Theory: Learning from Each Other. Symphonya. Emerging Issues in Management, 2017, pp. 1, 7.

[24] Benlemlih, M. \& Bitar, M, Corporate Social Responsibility and Investment Efficiency. 
Journal of Business Ethics, 2018, 148(3), pp. $647-671$.

[25] Khan, A., Muttakin, M.B., \& Siddiqui, J, Corporate Governance and Corporate Social Responsibility Disclosures: Evidence from An Emerging Economy. Journal of Business Ethics, 2012, 114(2), pp. 207-223.

[26] O’Donovan, G. Legitimacy Theory as An Explanation for Corporate Environtmental Disclosures. Accounting and Finance, February, 2000.

[27] Fernando, S. \& Lawrence, S A Theoretical Framework for CSR Practices: IntegratingLegitimacy Theory, Stakeholder Theory, and Institutional Work. January, 2011, pp. 149-178.

[28] Biddle, G.C., Hilary, G., \& Verdi, R.S, How Does Financial Reporting Quality Relate to Investment Efficiency? Journal of Accounting and Economics, 2009, 48(2-3), pp. 112-131.

[29] Gray, R., Owen, D., \& Maunders, K, Corporate Social Reporting: Emerging Trends in Accountability and the Social Contract. Accounting, Auditing \& Accountability, 1988, 1(1), pp. 6-20.

[30] Mathews, M.R, Social and Environmental Accounting: A Practical Demonstration of Ethical Concern? Journal of Business Ethics, 1995, 14(8), pp. 663-671.

[31] Shahzad, F., Rehman, I.U., Colombage, S., \& Nawaz, F, Financial Reporting Quality, Family Ownership, and Investment Efficiency: An Empirical Investigation.
Managerial Finance, 2019, 45(4), pp. 513-535.

[32] Tsao, S.M., Chang, Y.W., \& Koh, K, Founding Family Ownership and Myopic R\&D Investment Behavior. Journal of Accounting, Auditing, and Finance, 2017, 34(3), pp. 361-384.

[33] Attig, N., Boubakri, N., El Ghoul, S., \& Guedhami, O, The Global Financial Crisis, Family Control, and Dividend Policy. Financial Management, 2016, 45(2), pp. 291-313.

[34] Berrone, P., Cruz, C., Gómez-Mejía, L.R., \& Larraza-Kintana, M, Socioemotional Wealth and Corporate Responses to Institutional Pressures: Do Family-Controlled Firms Pollute Less? Administrative Science Quarterly, 2010, 55(1), pp. 82-113.

[35] Deephouse, D.L., \& Jaskiewicz, P, Do Family Firms Have Better Reputations Than Non-Family Firms? An Integration of Socioemotional Wealth and Social Identity Theories. Journal of Management Studies, 2013, 50(3), pp. 337-360.

[36] Aerts, W., Cormier, D., \& Magnan, M, Corporate Environmental Disclosure, Financial Markets and the Media: An International Perspective. Ecological Economics, 2008, 64(3), pp. 643-659.

[37] Shahzad, F., Rehman, I.U., Mir, F.N., \& Nawab, N, Does Family Control Explain Why Corporate Responsibility Affects Investment Efficiency? Corporate Social Responsibility and Environmental Management, 2018, 25(5).

[38] Raar, J, Environmental Initiatives: Towards Triple-Bottom Line Reporting. Corporate Communications: An International Journal, 2002, 7(3), pp. 169-183. 